\title{
Caloglossa beccarii (Delesseriaceae, Rhodophyta) from freshwater rivers in Kerala, India, a critical new record
}

\author{
John A. West ${ }^{1, *}$, Mitsunobu Kamiya ${ }^{2}$, E. K. Ganesan ${ }^{3}$, Susan Louiseaux-de Goër ${ }^{4}$ and L. Jose ${ }^{5}$ \\ ${ }^{1}$ School of Botany, University of Melbourne, Parkville, Victoria 3010, Australia \\ ${ }^{2}$ Faculty of Marine Bioscience Fukui Prefectural University, 1-1 Gakuencho, Obama, Fukui 917-0003, Japan \\ ${ }^{3}$ Instituto Oceanográfico, Universidad de Oriente, Cumaná 6101, Venezuela \\ ${ }^{4} 11$ Rue des Moguerou, 29680 Roscoff, France \\ ${ }^{5}$ Department of Botany, St. Albert's College, Ernakulam, Kerala 682018, India
}

Caloglossa species occurs in freshwater streams around Southest Asia. We report it from 2 different riverine sites in Kerala, India. Tetrasporangiate plants were observed in field collections from the Periyar River and Chalakkudy River. The Chalakkudy isolate did not reproduce in culture but the Periyar isolate developed abundant tetrasporangial sori in culture. Many spores were discharged and most were abortive, but some germinated normally, sporelings forming male gametophytes with numerous spermatangial sori and females with many procarps, viable carposporophytes and some nonfunctional (no carpospores) pseudocystocarps. Some carpospores germinated forming new tetrasporophytes. Molecular evidence ( $28 \mathrm{~S}$ rDNA and $r b c \mathrm{~L}$ ) placed the Indian specimens close to C. beccarii and C. fluviatilis. Considering the freshwater habitat and morphology of vegetative thalli (blade shape, rhizoid arrangement, and number of rhizoid filament per cell), the Indian specimens should be assigned to $C$. beccarii.

Key Words: Caloglossa beccarii; Caloglossa fluviatilis; India; Kerala; LSU; rbcL

\section{INTRODUCTION}

The Ceramiales is the most varied order among red algae (ca. 420 genera, 2,660 species) (Guiry and Guiry 2015), but only a few genera have been found from freshwater habitats. The genus Caloglossa (Delesseriaceae, Ceramiales) is widespread in tropical to temperate mangrove, estuarine and freshwater habitats. It is comprised of 22 currently accepted species (Guiry and Guiry 2015), and the following six species have been reported from freshwater streams.

Caloglossa beccarii (Zanardini) DeToni was described as Delesseria beccarii Zanardini that occurred with Tho- rea flagelliformis Zanardini in a freshwater stream near Gunung Pueh in Sarawak, Malaysia (Zanardini 1872, Beccari 1904). The species is recorded as "epilithic on stones in freshwater coastal streams and epiphytic on mangrove trunks, prop roots and pneumatophores in areas with moderate water flow and high turbidity and restricted to south-east Asia (India, Burma, Malaysia, Indonesia, Singapore), the western Pacific, and northern Australia as far south as $28^{\circ} \mathrm{S}^{\prime \prime}$ (King and Puttock 1994, Kamiya et al. 2003). On Guadalcanal, Solomon Islands, Womersley and Bailey (1970) recorded it growing in a swimming hole near
(9) \$ This is an Open Access article distributed under the terms of the Creative Commons Attribution Non-Commercial License (http://creativecommons.org/licenses/by-nc/3.0/) which permits unrestricted non-commercial use, distribution, and reproduction in any medium, provided the original work is properly cited.
Received July 2, 2015, Accepted August 30, 2015

*Corresponding Author

E-mail: jwest@unimelb.edu.au

Tel: +61-3-8344-8080, Fax: +61-3-9347-5460 
A

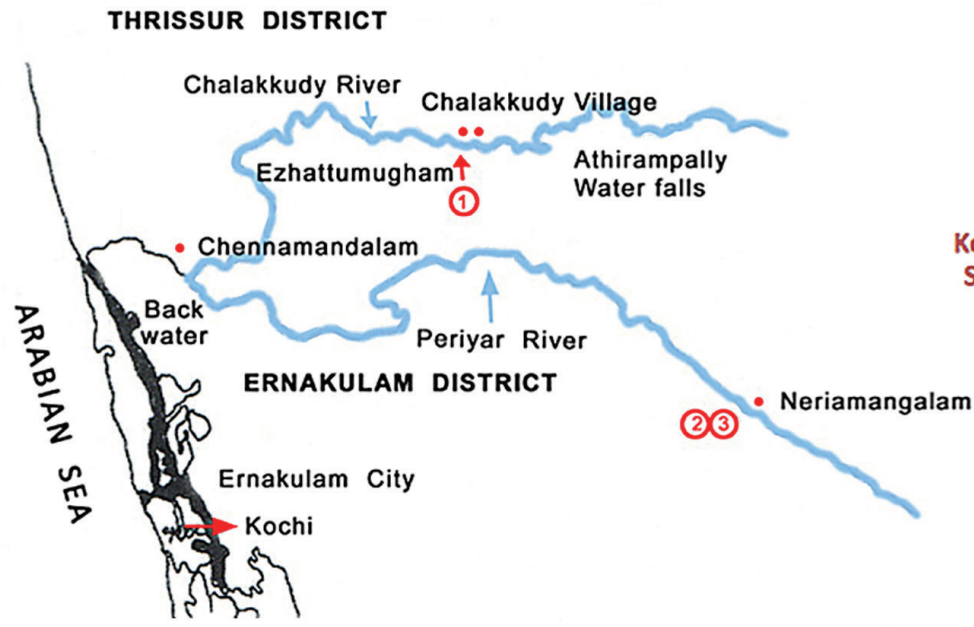

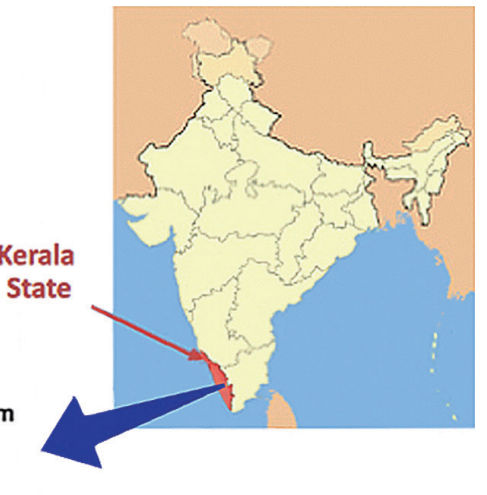

Map of India showing

the collection places in two Kerala Rivers
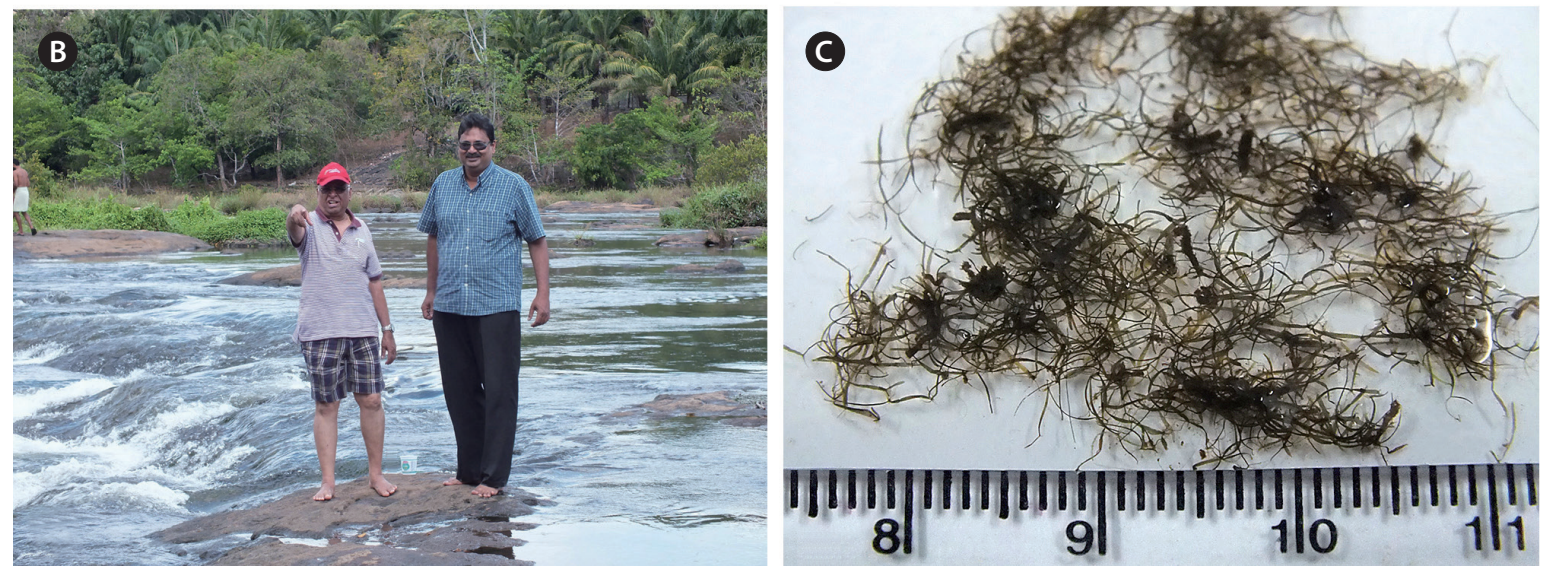

Fig. 1. (A) Map of Kerala, India showing Periyar and Chalakkudy River collecting sites. (B) Ganesan and Jose collecting at Ezhattumugham, Chalakkudy River in 2013, showing solid rock substrate and topography. (C) Habit of field specimens from Ezhattumugham, Chalakkudy River.

the mouth of a freshwater stream where it was subject to seawater at high tide. The first reported Indian specimen was obtained by Biswas in 1936 from the Hooghly River at the Calcutta Botanical Garden (now Ancharya Jagadish Chandra Bose Indian Botanic Garden) (http://www.nhn. leidenuniv.nl/index.php/institute). Unfortunately no herbarium specimens are available in the National Herbarium in Leiden, The Netherlands or the National Botanical Garden in Calcutta so this record is unsubstantiated. $C$. beccarii also has been found in other SE Asian countries including Thailand (Sato and Akiyama 2001), Vietnam (Kamiya et al. 2003) and in freshwater rivers $\left(24-29^{\circ} \mathrm{C}, \mathrm{pH}\right.$ 7-8, conductivity 40-50 $\mu \mathrm{S} \mathrm{cm}^{-2}$ ) in Selangor and Negeri Sembilan of peninsular Malaysia (Johnston et al. 2014).

C. beccarii, which had been recorded from a freshwater habitat in the Pédro Miguel Locks of the Panama Canal (US Alg. Type Coll. 217746) (Lin et al. 2001), was redesignated as a new species, C. fluviatilis Krayesky, Fredericq et J. N. Norris (Krayesky et al. 2012), because, in addition to the distinct phylogenetic relationship, the rhizoidal arrangement and nodal constriction of blades are distinct from those of C. beccarii (Krayesky et al. 2012).

The closely related C. ogasawaraensis Okamura was first described from the Ogasawara Islands of southern Japan (Okamura 1897) and is now widely recorded in marine, estuarine and freshwater habitats around the world (eastern USA; King and Puttock 1994, West and Zuccarello 1995) (Central and South America; Sheath et al. 1993, Pedroche et al. 1995, Krayesky et al. 2012, Zuccarello et al. 2012) (Australia, Micronesia, southeast Asia and Madagascar; Kamiya and West 2014). Caloglossa ogasawaraensis (as C. ogassuarensis Skuja) was observed in freshwater streams of Costa Rica by Soto (1982) and was first recorded from freshwater in India by Jose and Patel (1990).

Caloglossa leprieurii (Montagne) G. Martens was col- 
lected from a freshwater stream in Puerto Rico (Sheath et al. 1993). In Australia C. vieillardii (Kützing) Setchell was recorded from freshwater at the Hopkins River Waterfall, Victoria and Jacksons Creek, Organ Pipes National Park, Victoria, Australia (as C. leprieurii) (West and Kraft 1996, West et al. 2001). In China C. saigonensis (as C. leprieurii var. angusta) was found in Szechwan Province near Pehpei on the Jialing River, over 1,500 km from the Yangtze River mouth near Shanghai (Jao 1941).

We have investigated the Caloglossa populations in Kerala for several years and compared them with various species using morphological, culture and molecular analyses and think it is now important to clarify general biological and taxonomic aspects of the Kerala populations.

\section{MATERIALS AND METHODS}

Collection details are shown in Fig. 1A map and Table 1. The Chalakkudy River general habitat and the collectors, L. Jose and E. K. Ganesan, are shown in Fig. 1B and the typical habit of a field collected plant is in Fig. 1C. Herbarium specimens of $C$. beccarii from Neriamangalam, Kerala are deposited in University of Michigan Herbarium (MICH 684329) and University and Jepson Herbaria, University of California, Berkeley (UC/JEPS 2050401).

\section{Culture methods}

Isolation and culture methods are similar to those used in earlier work (West et al. 2001, West 2005). Irradiance was $10: 14 \mathrm{~h}$ diurnal light-dark, cool white LEDs or cool white fluorescent lamps (3-12 $\mu \mathrm{mol}$ photons $\mathrm{m}^{-2} \mathrm{~s}^{-1}$ ) and temperature $18-22^{\circ} \mathrm{C}$ air-conditioning. Although the field specimens were collected in very low salinity $(<0.5)$ we cultured them in salinities of 2 or 5 with standard modified Provasoli's medium (MPM) supplemented with peat extract to mimic tannin levels in tropical freshwater rivers. Sterile peat extract was prepared as $500-\mathrm{mL}$ MilliQ water, $15 \mathrm{~g}$ peat moss (commercial garden package), steam sterilized for $30 \mathrm{~min}$, cooled, vacuum filtered with two sheets of Whatman No. $1(9 \mathrm{~cm})$, re-sterilized and stored at $4^{\circ} \mathrm{C}$. The extract fluid was clear and dark brown. One litre of culture medium was prepared as $975-\mathrm{mL}$ MilliQ water, $5 \mathrm{~mL}$ peat extract, $10 \mathrm{~mL}$ seawater (salinity of 30), and $10 \mathrm{~mL}$ MPM nutrient enrichment. This has been useful for culturing many red algae from freshwater / low salinity habitats.

\section{Molecular analyses}

The DNA extraction method, polymerase chain reaction (PCR) conditions, and sequencing procedure

Table 1. Caloglossa beccarii collection locations, substrates, temperatures, salinities, reproduction, collectors, and dates, Kerala, India

\begin{tabular}{|c|c|c|c|}
\hline Location & Collecting date & Collector & Note \\
\hline $\begin{array}{l}4 \text { km upstream from Ezhattumugham, } \\
\text { Chalakkudy R. }\left(10^{\circ} 17.746^{\prime} \mathrm{N}, 76^{\circ} 22.084^{\prime} \mathrm{E}\right)\end{array}$ & Nov 24, 2012 & Jose & $\begin{array}{l}\text { Indial (sample name); } \\
\text { tetrasporophyte; on solid rocks in } \\
\text { fast running clear water }\end{array}$ \\
\hline \multirow[t]{3}{*}{ Ezhattumugham, Chalakkudy R. } & Apr 16, 2013 & Jose & $\begin{array}{l}\text { Vegetative; on solid rocks, fast running } \\
\text { clear water, elevation } 140 \mathrm{~m}\end{array}$ \\
\hline & Oct 9,2013 & Jose and Ganesan & Vegetative \\
\hline & Dec 7, 2013 & Jose and Ganesan & Vegetative \\
\hline $\begin{array}{l}\text { Maniyanpara (between Chembankuzhi and } \\
\text { Nereamangalam), Periyar R., Idukki District } \\
\left(10^{\circ} 3.384^{\prime} \mathrm{N}, 76^{\circ} 48.110^{\prime} \mathrm{E}\right)\end{array}$ & Oct 6,2013 & Jose & $\begin{array}{l}\text { India2 (sample name); vegetative; } \\
\text { elevation } 45 \mathrm{~m}\end{array}$ \\
\hline $\begin{array}{l}\text { Ezhattumugham, Chalakkudy R. } \\
\left(10^{\circ} 17.746^{\prime} \mathrm{N}, 76^{\circ} 22.084^{\prime} \mathrm{E}\right)\end{array}$ & Feb 13, 2014 & $\begin{array}{l}\text { Jose, Ganesan, and } \\
\text { West }\end{array}$ & $\begin{array}{l}\text { India3 (sample name); } \\
\text { tetrasporophyte; on shaded solid } \\
\text { rocks in fast running clear water, } \\
\text { water temp. } 32^{\circ} \mathrm{C} \text {, salinity } 0.1\end{array}$ \\
\hline $\begin{array}{l}\text { Nereamangalam cacao plantation, Periyar R. } \\
\quad\left(10^{\circ} 2.547^{\prime} \mathrm{N}, 76^{\circ} 47.777^{\prime} \mathrm{E}\right)\end{array}$ & Feb 14, 2014 & $\begin{array}{l}\text { Jose, Ganesan, and } \\
\text { West }\end{array}$ & $\begin{array}{l}\text { India4 (sample name); vegetative; on } \\
\text { submerged rocks and sandbags ( } 30 \text { - } \\
50 \mathrm{~cm} \text { deep) in wide, slow moving, } \\
\text { murky water, water temp. } 26^{\circ} \mathrm{C} \text {, } \\
\text { salinity } 0.2\end{array}$ \\
\hline
\end{tabular}



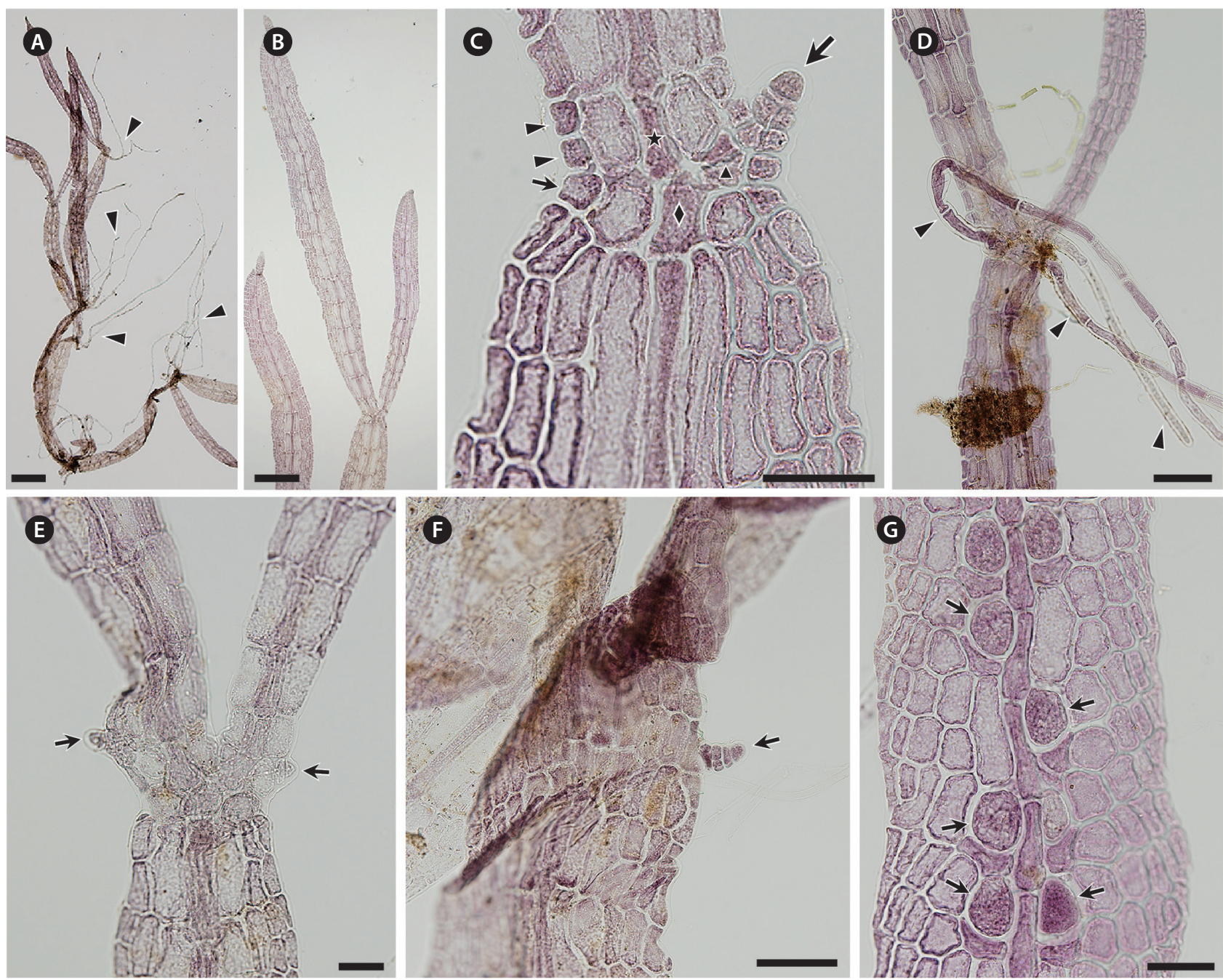

Fig. 2. Field specimens collected from Chalakkudy River, Kerala, India on November 24, 2012. (A) Whole thallus. Several rhizoidal filaments are produced from the ventral side of the nodes (arrowheads). (B) Slightly constricted node. (C) Part of thallus at second node from apex. Lateral axis (large arrow) is still diminutive. Nodal cell (diamond) produces one cell row (small arrow) toward main axis side. First axial cell of lateral axis (triangle) forms one cell row on adaxial side. First axial cell of the main axis (star) produces two cell rows (arrowheads) opposite lateral blade. (D) Rhizoidal filaments (arrowheads) produced from pericentral cells at node. (E) Adventitious blade initials (arrows) developed from lateral pericentral cells of first axial cell above node. (F) An adventitious blade initial (arrow) derived from internodal marginal cell. (G) Immature tetrasporangia (arrows). Scale bars represent: A, $500 \mu \mathrm{m} ; \mathrm{B}, 200 \mu \mathrm{m} ; \mathrm{C}, \mathrm{E} \& \mathrm{G}, 50 \mu \mathrm{m} ; \mathrm{D} \& \mathrm{~F}, 100 \mu \mathrm{m}$.

Table 2. The information of primers for PCR and sequencing

\begin{tabular}{clll}
\hline Target & Primer name & \multicolumn{1}{c}{ Primer sequence (5'-3') } & Direction \\
\hline LSU rDNA (for PCR) & LSU-YF & GCAGGACGGTGGCCATGGAAGT & Forward \\
& LSU-ZR & TGATAGGAAGAGCCGACATCGA & Forward \\
LSU rDNA (for sequencing) & LSU-ZF2 & CCGTAACTTTGGGAAAAGGGTTGGC & Reverse \\
& LSU-YR2 & CGGATTCCCTTTGCCCGTTGCRGTTC & Forward \\
$r b c$ L (for PCR) & rbc-F3 & ATGTCTAACTCTGTAGAAGAACGGAC & Reverse \\
& rbc-R4c & GGRTGTGGATCWTCWGTATAYTC & Reverse \\
$r b c$ L (for sequencing) & rbc-R6b & GCWACACGRTTWGCTGTTGCWCC & Forward \\
& rbc-F7 & GGTATYCAYTGYGGWCARATGC & Reverse \\
\hline
\end{tabular}

PCR, polymerase chain reaction; LSU rDNA, large subunit of rDNA. 
followed Hayakawa et al. (2012); specifically PCR and sequencing were carried out on the large subunit of rRNA (LSU) gene and the large subunit of RuBiSCO $(r b c \mathrm{~L})$ gene. DNA was extracted using field-collected specimens from Chalakkudy River (Indial) and from Periyar River (India2). The sequences of primers used for PCR and sequencing are presented in Table 2. The sequence data were deposited in the DNA Data Bank of Japan (http:// www.ddbj.nig.ac.jp) (LC065028-LC065031).

The methods for alignment of sequence data and construction of phylogenetic trees were the same as those described by Kamiya and West (2014). Adjustments of the resulting alignments were performed manually, resulting in 1,329 bp for LSU and 1,417 bp for rbcL. Using the program Kakusan4 (Tanabe 2011), the best-fitted substitution model was estimated for maximum likelihood (ML) analysis on the basis of the corrected Akaike information criterion (TN $+\mathrm{G}$ and GTR $+\mathrm{G}$ for LSU and $r b c \mathrm{~L}$, respectively) and for Bayesian inference (BI) analysis based on the Bayesian information criterion (K80 + G and GTR + G for LSU and $r b c \mathrm{~L}$, respectively).

\section{RESULTS}

\section{Morphological observations}

Thalli collected in the Periyar River on February 14, 2014 were growing on shallow rocks, dark red to brown, forming densely branched tufts up to $2 \mathrm{~cm}$ high (Figs 1C \& 2A). The blades branched subapically and were linear to narrowly lanceolate, slightly constricted at the nodes, up to $4.5 \mathrm{~mm}$ long (Fig. 2B). Blade width was 50-160 $\mu \mathrm{m}$ at the upper part, $90-320 \mu \mathrm{m}$ at the middle part, and $40-120 \mu \mathrm{m}$ at the lower part. Initials of lateral axes were frequently seen not only at the first but at the second or third nodes because of their slower elongation than the main axes (Fig. 2C). The numbers of cell rows around the node, which are the important characters for identifying Caloglossa species, were as follows: one or occasionally two adaxial cell rows form from the first axial cell at the lateral axis; the nodal axial cell producing one cell row (small arrow in Fig. 2C) and the first axial cells of the main axis (FMA) forming one or two cell rows opposite the lateral blade (arrowheads in Fig. 2C). A single rhizoid filament, 20-35 $\mu \mathrm{m}$ in diameter and up to $4 \mathrm{~mm}$ long (Fig. 2D), was derived from a pericentral cell at the node or immediately above and below the node. No wing cells produced rhizoid filaments. Adventitious secondary blades occasionally arose from the first axial cell above the node at the same plane as that of the thallus (Fig. 2E), rarely from the marginal cells at the internodes (Fig. 2F); endogenous blades were not seen. We observed only a few plants with immature tetrasporangia (Fig. 2G). Gametophytes with sexual reproductive structures were never found in the field. All the above observations were made with dried field specimens.

Both strains (4840 from Chalakkudy River and 4841 from Periyar River) were cultured, initially in a salinity of 5 at low photon fluence rates (3-5 $\mu \mathrm{mol}$ photons $\left.\mathrm{m}^{-2} \mathrm{~s}^{-1}\right)$ for $2-3$ months and then shifted to $>10 \mu \mathrm{mol}$ photons $\mathrm{m}^{-2} \mathrm{~s}^{-1}$ for 4 months. Isolate 4840 grew more slowly than 4841 and did not reproduce in over one year of culture. By contrast 4841 grew robustly, plants reaching $>20 \mathrm{~mm}$ in 3 months (Fig. 3A). After four months robust tetrasporangial sori developed (Fig. 3A \& B) and many spores were discharged but germination was poor. However surviving sporelings (Fig. 3C) grew well and after 7 months male gametophytes developed spermatangial sori (Fig. 3D \& E) with normal spermatia released. As in field specimens, adventitious blades of cultured blades were derived from internodal marginal wing cells of vegetative blade (Fig. 3F). Female gametophytes developed carpogonial branches along the midrib (Fig. 4A \& C). Numerous carposporophytes developed in about one month (Fig. 4B \& D) and discharged some carpospores from which a few sporelings developed. Also some 'pseudocystocarps' developed that did not form carpospores (Fig. 4E). Although at a salinity of 5 the thalli grew well and reproduced, the overall viability of spores was low. We attempted culturing field collected plants initially at a salinity of 1-2 but survival and growth were not as good as in a salinity of 5 . It is puzzling that tetraspore and carpospore survival and germination were low at a salinity of 5 .

\section{Phylogenetic analyses}

The two Indian specimens (Indial from Chalakkudy River and India2 from Periyar River) showed only one bp substitution in the LSU sequences. The LSU analyses revealed that these Indian specimens made a clade with C. fluviatilis from Panama (57\% ML support and $0.61 \mathrm{BI}$ support) (Fig. 5). The relationship between this clade and C. beccarii from Singapore, Vietnam and Thailand was unresolved.

The $r b c \mathrm{~L}$ sequences of the two Indian specimens (Indial and India2) were identical. In the $r b c$ L phylogeny, they were also related to C. fluviatilis but it was weakly supported (56\% ML support and 0.84 BI support) (Fig. 6). Their relationship with $C$. beccarii was unresolved. 

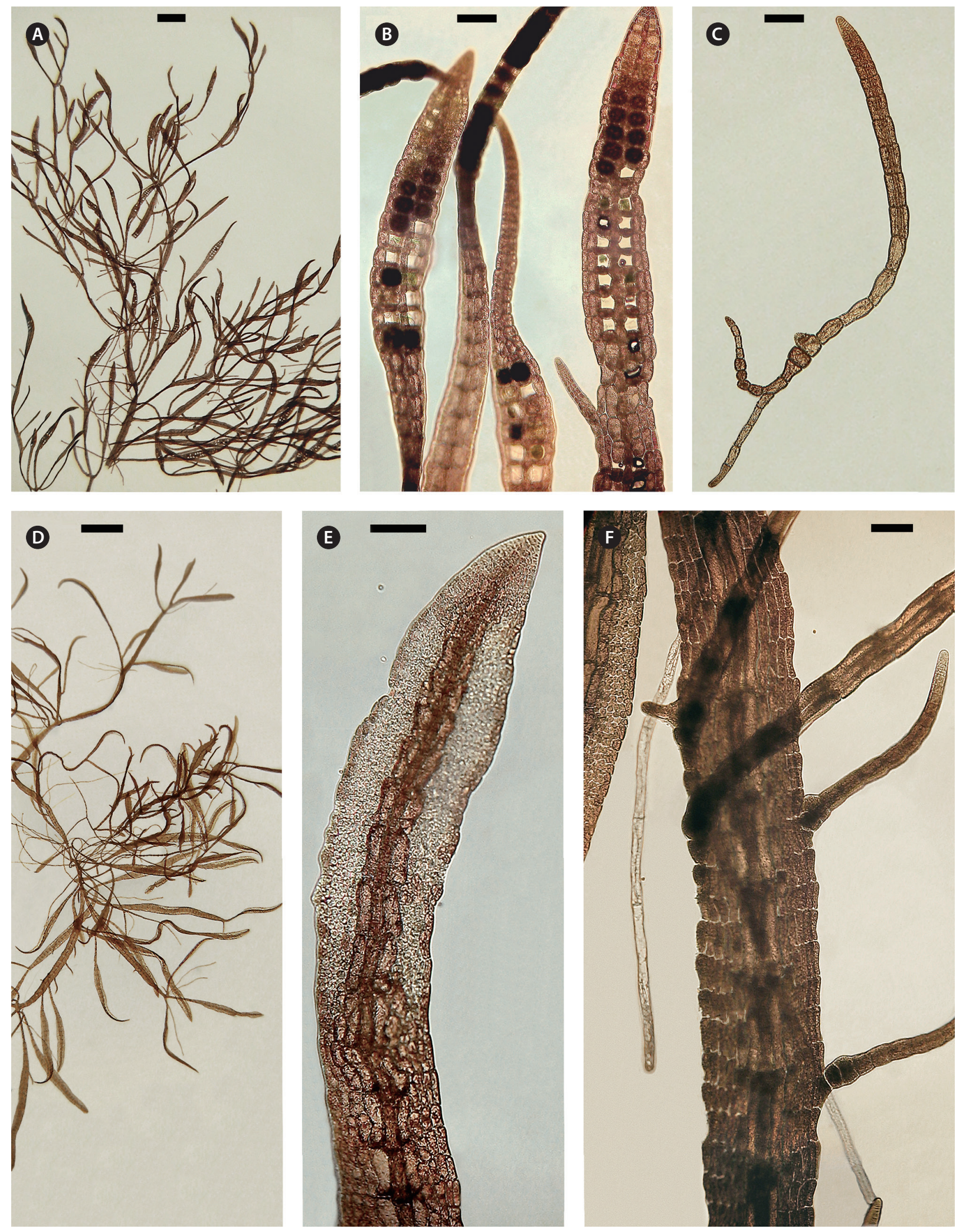

Fig. 3. (A) Habit of culture 4841 showing branching, nodes and tetrasporangial sori. (B) Tetrasporangial sori (single row of sporangia on each side of midrib) showing developing, mature and discharged sporangia. (C) Young tetraspore germling with upper blade and rhizoids at base. (D) Mature male with spermatangial sori on many blades. (E) Blade tip with elongate spermatangial sori. (F) Adventitious blades from intermodal marginal wing cells of vegetative blade like that of field specimen, Fig. 2F. Scale bars represent: A \& D, 1 mm; B, C, E \& F, $100 \mu \mathrm{m}$. 

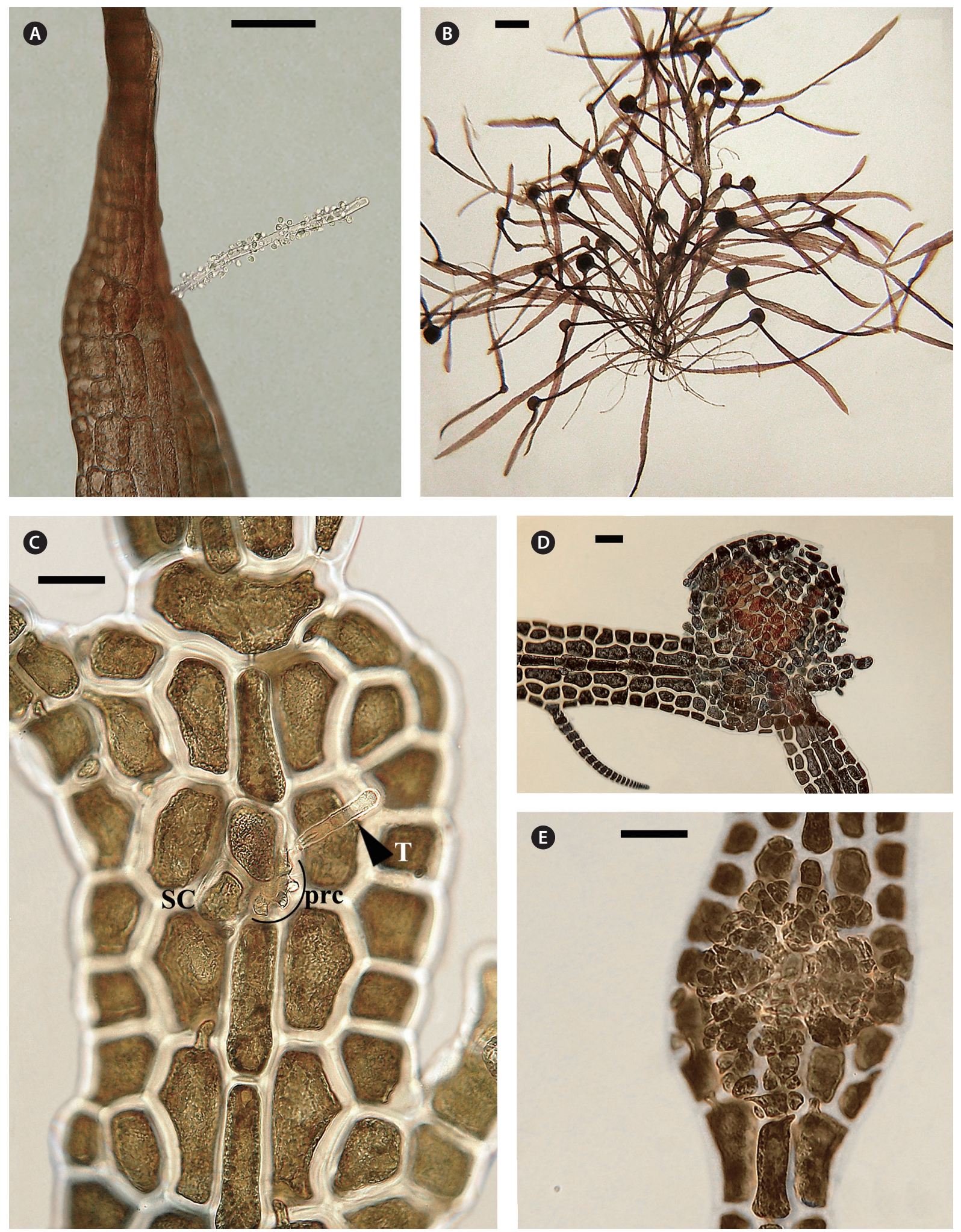

Fig. 4. (A) Female trichogyne with numerous attached spermatia. (B) Female with numerous developing and mature carposporophytes. (C) Female with supporting cell (sc), carpogonial branch (prc) and trichogyne (arrowhead) on blade midrib. (D) Lateral view of young cystocarp with normal pericarp and gonimoblast with developing carposporangia visible underneath. Lightly stained with anilin blue. (E) Face view of pseudocystocarp with pericarp enclosing ostiole in center. Panels $C, D$, and E were treated with $10 \mathrm{~s} .800 \mathrm{~W}$ microwave to shrink cells. Scale bars represent: $A \& D, 100 \mu \mathrm{m} ; B, 500 \mu \mathrm{m} ; C, 25 \mu \mathrm{m} ; E, 50 \mu \mathrm{m}$. 


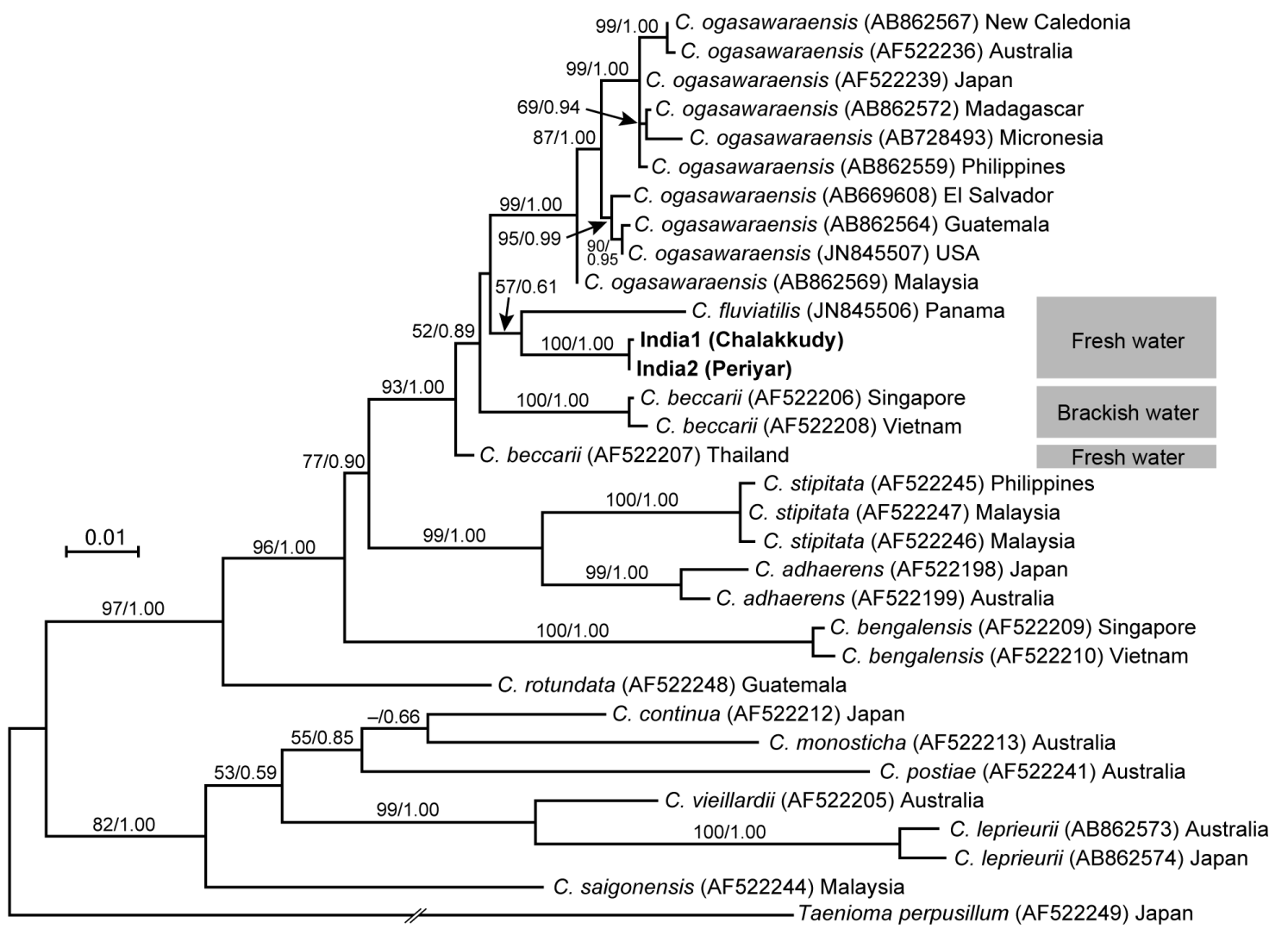

Fig. 5. Maximum-likelihood (ML) phylogeny of Caloglossa species inferred from the partial large subunit of rRNA gene sequences. Taenioma perpusillum (J. Agardh) J. Agardh was used as an outgroup. The bootstrap values for ML ( $>50 \%$; left) and posterior probabilities for Bayesian inference ( $\geq 0.80$; right) are presented for each branch. Accession number, strain number or sample name is shown in each parenthesis.

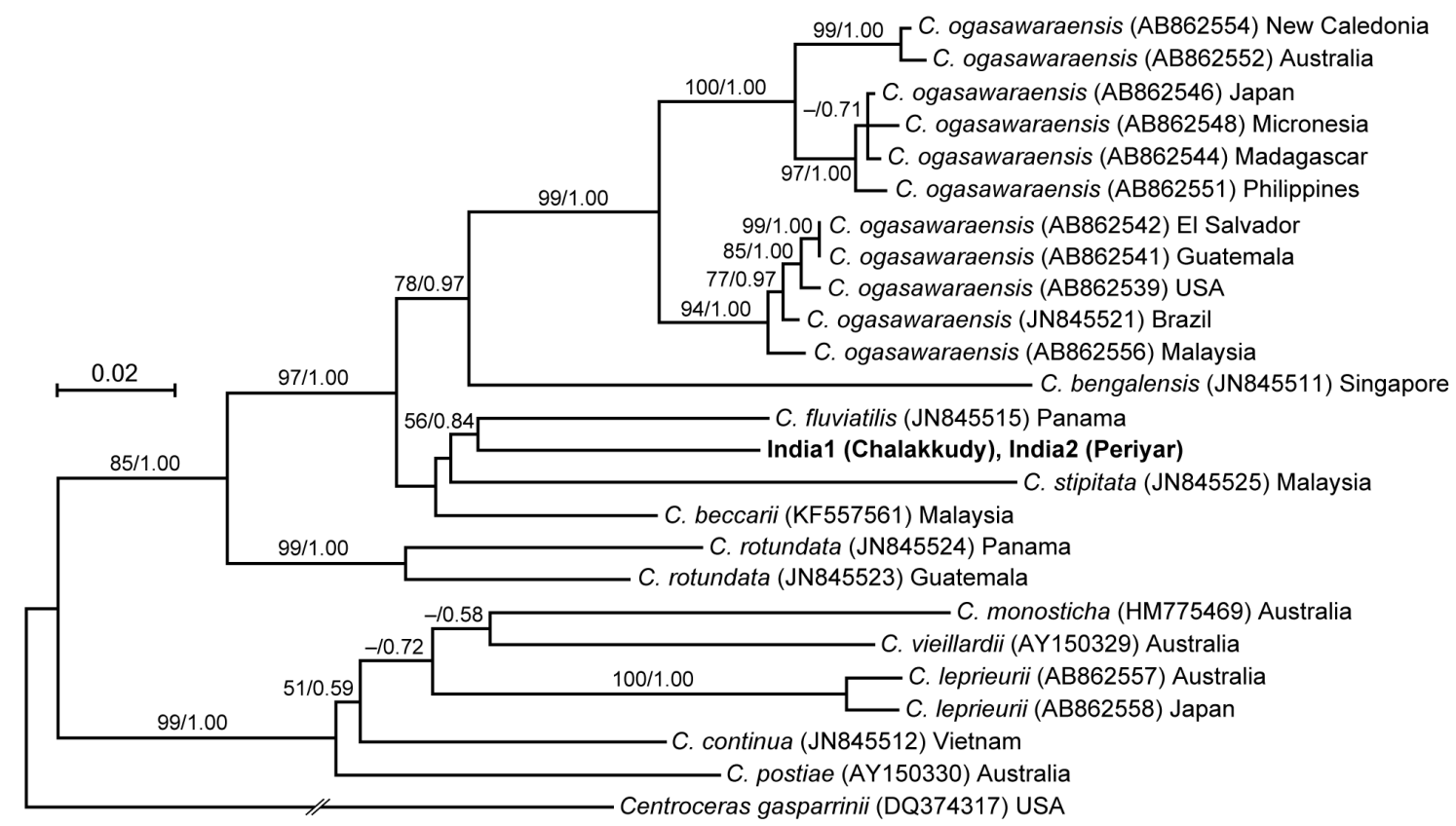

Fig. 6. Maximum-likelihood phylogeny of Caloglossa species inferred from the partial rbcL gene sequences. Centroceras gasparrinii (Meneghini) Kützing was used as an outgroup. Other information is in the Fig. 5 legend. 


\section{DISCUSSION}

Although the freshwater Caloglossa species are present in various temperate and tropical regions of the world neither the general biology nor molecular relationships have been investigated adequately. How did these transitions from the marine and estuarine habitats to freshwater occur? How have growth, reproduction and physiology changed in these radically different conditions? They are also subjected to a different set of cohabitants, plants, animals and pathogens. Grazing by different animals may require different defense mechanisms (Goodman and Hay 2013).

In both LSU and $r b c \mathrm{~L}$ trees, the present alga made a clade with C. fluviatilis, which was not supported by high values of bootstrap and BI analyses. C. fluviatilis is separated from $C$. beccarii by forming rhizoids from nodal pericentral cells and adjacent wing cells (type $\mathrm{F}$ in Kamiya et al. 2003) and multiple rhizoid filaments per cell (Krayesky et al. 2012). It is occasionally difficult to delineate the arrangement pattern of rhizoids around the node, especially type D, E, and F, which are distinguished by the presence / absence of rhizoids derived form wing cells (Kamiya et al. 2003). This feature may be affected by blade width because the number of wing cells around the nodes tend to be fewer in slender thalli (Kamiya unpublished data). By contrast, the number of rhizoid derived from a cell is relatively stable and clear-cut in most $\mathrm{Ca}$ loglossa species (Kamiya et al. 2003), and the Indian alga, which has single rhizoid filament per cell, is distinguishable from C. fluviatilis.

This alga is similar to C. ogasawaraensis based on the slender blades and the production of rhizoids only from pericentral cells around the nodes (type E in Kamiya et al. 2003). Actually Jose and Patel (1990) identified the specimen collected from Sholayar River, Kerala India as C. ogasawaraensis. However, C. ogasawaraensis produces only one cell row from FMA (Kamiya and West 2014), whereas the present alga sometimes forms two cell rows (Fig. 2C). This feature is used to distinguish C. vieillardii (mainly one cell row) from C. leprieurii (2-4 cell rows), which are phylogenetically distinct from each other (Kamiya et al. 2003). The disjunction between the Indian specimens and C. ogasawaraensis is also supported by our phylogenetic analyses.

A monophyletic relationship of C. beccarii was not supported in this study; the LSU three shows that the specimens collected from brackish water habitats in Singapore and Vietnam were distinct from that from a freshwater habitat in Thailand. Kamiya et al. (2003) carried out the detailed morphological observation of $C$. beccarii collected from both brackish and freshwater habitats but could not find any remarkable difference between them. Nevertheless, considering the common features, one or two cell rows numbers from FMA and single rhizoid filament per cell, the present alga should be assigned to $C$. beccarii. Because populations of $C$. beccarii examined is limited, more extensive samplings and culture experiments is necessary to delimitate this species.

\section{ACKNOWLEDGEMENTS}

This research was sponsored partially by JSPS Kakenhi (19570092) to MK, personal funds of JW, various Australian Research Council grants from 1994-2000, a grant from the Australian Biological Resources Study (20022005) and the Hermon Slade Foundation (2003-2007) to JW. Arjun Thomas assisted with collecting at Neraimangalam February 15, 2014.

\section{REFERENCES}

Beccari, O. 1904. Wanderings in the Great Forests of Borneo. Archibald Constable \& Co. Ltd., London, 424 pp.

Goodman, K. M. \& Hay, M. E. 2013. Activated chemical defenses suppress herbivory on freshwater red algae. Oecologia 171:921-933.

Guiry, M. D. \& Guiry, G. M. 2015. AlgaeBase. World-wide electronic publication, National University of Ireland, Galway. Available from: http://www.algaebase.org. Accessed Feb 10, 2015.

Hayakawa, Y., Ogawa, T., Yoshikawa, S., Ohki, K. \& Kamiya, M. 2012. Genetic and ecophysiological diversity of Cladophora (Cladophorales, Ulvophyceae) in various salinity regimes. Phycol. Res. 60:86-97.

Jao, C. C. 1941. Studies on the freshwater algae of China VIII. A preliminary account of the Chinese freshwater Rhodophyceae. Sinensia 12:245-290.

Johnston, E. T., Lim, P. -E., Buhari, N., Keil, E. J., Djawad, M. I. \&Vis, M. L. 2014. Diversity of freshwater red algae (Rhodophyta) in Malaysia and Indonesia from morphological and molecular data. Phycologia 53:329-341.

Jose, L. \& Patel, R. J. 1990. Caloglossa ogasawaraensis (Rhodophyta, Delesseriaceae), a freshwater Rhodophyceae new to India. Cryptogam. Algol. 11:225-228.

Kamiya, M. \&West, J. A. 2014. Cryptic diversity in the euryhaline red alga Caloglossa ogasawaraensis (Delesseriaceae, Ceramiales). Phycologia 53:374-382. 
Kamiya, M., Zuccarello, G. C. \&West, J. A. 2003. Evolutionary relationships of the genus Caloglossa (Delesseriaceae, Rhodophyta) inferred from large-subunit ribosomal RNA gene sequences, morphological evidence and reproductive compatibility, with description of a new species from Guatemala. Phycologia 42:478-497.

King, R. J. \& Puttock, C. F. 1994. Morphology and taxonomy of Caloglossa (Delesseriaceae, Rhodophyta). Aust. Syst. Bot. 7:89-124.

Krayesky, D. M., Norris, J. N., West, J. A., Kamiya, M., Viguerie, M., Wysor, B. S. \& Fredericq, S. 2012. Two new species of Caloglossa (Delesseriaceae, Rhodophyta) from the Americas, C. confusa and C. fluviatilis spp. nov. Phycologia 51:513-530.

Lin, S. -M., Fredericq, S. \& Hommersand, M. H. 2001. Systematics of the Delesseriaceae (Ceramiales, Rhodophyta) based on large subunit rDNA and $r b c \mathrm{~L}$ sequences, including the Phycodryoideae, subfam. nov. J. Phycol. 37:881-899.

Okamura, K. 1897. On the algae from Ogasawara-jima (Bonin Islands). Bot. Mag. Tokyo 11:1-17.

Pedroche, F. F., West, J. A., Zuccarello, G. C., Senties, A. G. \& Karsten, U. 1995. Marine red algae of the mangroves in Southern Pacific México and Pacific Guatemala. Bot. Mar. 38:111-120.

Sato, H. \& Akiyama, H. 2001. Caloglossa beccarii (Ceramiales, Rhodophyta) from Thailand on the Malay Peninsula and its distribution in Southeast Asia. Nat. Hum. Act. 6:101104.

Sheath, R. G., Vis, M. L. \& Cole, K. M. 1993. Distribution and systematics of freshwater Ceramiales (Rhodophyta) in north America. J. Phycol. 29:108-117.

Soto, R. 1982. Caloglossa ogassuarensis Skuja (Rhodophyta, Ceramiales, Delesseriaceae) en Costa Rica. Brenesia 19:251-253.
Tanabe, A. S. 2011. Kakusan4 and Aminosan: two programs for comparing nonpartitioned, proportional and separate models for combined molecular phylogenetic analyses of multilocus sequence data. Mol. Ecol. Resour. 11:614-921.

West, J. A. 2005. Long-term macroalgal culture maintenance. In Andersen, R. (Ed.) Algal Culturing Techniques. Academic Press, New York, pp. 157-163.

West, J. A. \& Zuccarello, G. C. 1995. New records of Bostrychia pinnata and Caloglossa ogasawaraensis (Rhodophyta) from the Atlantic USA. Bot. Mar. 38:303-306.

West, J. A., Zuccarello, G. C. \& Kamiya, M. 2001. Reproductive patterns of Caloglossa species (Delessericeae, Rhodophyta) from Australia and New Zealand: multiple origins of asexuality in C. leprieurii. Literature review of apomixis, mixed-phase reproduction, bisexuality and self-compatibility. Phycol. Res. 49:183-200.

West, J. \& Kraft, G. 1996. Ectocarpus siliculosus (Dillwyn) Lyngb. from the Hopkins River Falls, Victoria. The first record of a freshwater brown alga in Australia. Muelleria 9:29-33.

Womersley, H. B. S. \& Bailey, A. 1970. Marine algae of the Solomon Islands. Philos. Trans. R. Soc. Lond. B Biol. Sci. 259:257-352.

Zanardini, G. 1872. Phycearum indicarum pugillus a $\mathrm{Cl}$. Eduardo Beccari ad Borneum, Sincapoore, et Ceylanum annis MDCCCLXV-VI-VIII collectarumqus cognitas determinavit, novasque descripsit iconibusque illustrare curvit Joannes Zanardini. Mem. R. Inst. Veneto Sci. Lett. Art. 17:129-170.

Zuccarello, G. C., Kamiya, M., Ootsuki, R., Loiseaux-de Goër, S., Pedroche, F. F. \& West, J. A. 2012. New records of red algae from mangroves in El Salvador and Pacific Mexico, combining culture and molecular observations. Bot. Mar. 55:101-111. 